\title{
ArcheoSciences
}

Revue d'archéométrie

33 (suppl.) | 2009

Mémoire du sol, espace des hommes

\section{Continuous Aquatic Soundings of the Lake Tere- Khol' Water Area in the Republic of Tuva (Russia)}

\section{A. Arzhantseva, M. A. Andreyev and I. N. Modin}

\section{(2) OpenEdition}

12 Journals

\section{Electronic version}

URL: https://journals.openedition.org/archeosciences/1652

DOI: 10.4000/archeosciences. 1652

ISBN: 978-2-7535-1599-4

ISSN: 2104-3728

Publisher

Presses universitaires de Rennes

\section{Printed version}

Date of publication: 30 October 2009

Number of pages: 255-257

ISBN: 978-2-7535-0943-6

ISSN: $1960-1360$

\section{Electronic reference}

I. A. Arzhantseva, M. A. Andreyev and I. N. Modin, "Continuous Aquatic Soundings of the Lake TereKhol' Water Area in the Republic of Tuva (Russia)", ArcheoSciences [Online], 33 (suppl.) | 2009, Online since 30 October 2011, connection on 01 February 2022. URL: http://journals.openedition.org/ archeosciences/1652; DOI: https://doi.org/10.4000/archeosciences.1652 


\title{
Continuous Aquatic Soundings of the Lake Tere-Khol' Water Area in the Republic of Tuva (Russia)
}

\author{
I. A. Arzhantseva*, M. A. Andreyev** and I. N. Modin **
}

Key words: geophysics, electrical method, Por-Bazhyn.

\section{INTRODUCTION}

The archaeological site of Por-Bajin (meaning " Clay House " in the local Tuva language) occupies a small island in Lake Tere-Khol', eight kilometers west of the Kungurtuk settlement in the southwestern part of the Republic of Tuva, Southern Siberia (Fig. 1). It consists of a rectangular enclosure around a complex of buildings and courtyards which is dominated by a central building. Its building materials and technology suggest that Por-Bajin was erected within the framework of the eighth-century Chinese building tradition. Located about $50 \mathrm{~km}$ from the border to Mongolia, at the headwaters of the Greater Yenisej River, Por-Bajin is more than an archaeological site with monumental architectural remains: it is situated in a unique environmental zone which is also deserving of study. Indeed, according to local legend the fortress was built on land and the lake emerged later. Therefore, the questions as to when and how the lake evolved are another area for scientific study.

Although known perhaps as early as the beginning of the eighteenth century, the site was not properly explored until the middle of the twentieth century when the island was recorded as measuring six hectares; by 2006, the island had been reduced to some four hectares in area. This gradual destruction of the island prompted the large-scale archaeo-

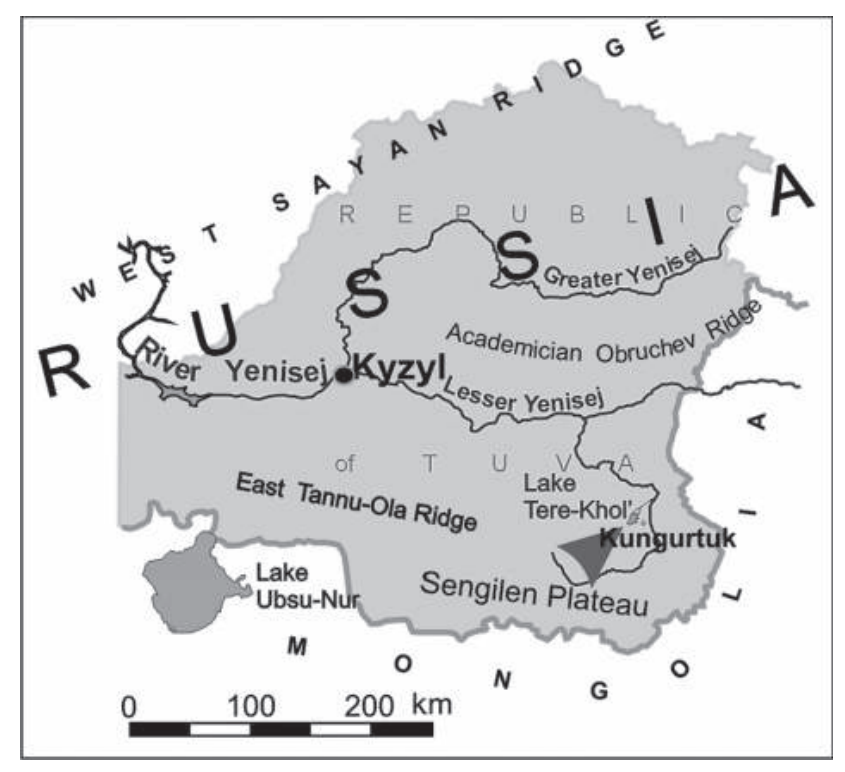

Figure 1: Geographical location of the lake.

logical investigation of Por-Bajin from May 2007 through September 2008, with researchers from Moscow State University, the Russian Academy of Sciences, and the State Museum of Oriental Art, Moscow.

* Institute of Ethnology, Russian Academy of Sciences, Moscow

** Faculty of Geology, Moscow State University 
During the summer season of 2007, continuous aquatic soundings were carried out on the lake Tere-Khol' water area (Khmelevskoy et al., 1988). The main purpose of the research which focused on sub-bottom sediments was to find archeological objects, such as dams, sunken islands, palaeochannels and other ancient terrain elements which could provide information on the general situation at the time of the building of the fortress. Contrary to the legend that the lake has an artificial origin (Wanstein, 1964), the first surveys and familiarization with the geological lay-out of the Tere-Khol' basin showed that the intermountain depression has existed since the late Neogene, has a depth of about $100 \mathrm{~m}$, and is filled up predominantly with fluviolacustrine deposits. Comparative analysis of satellite images and topographic maps dating from the last 30 years showed that the water area of the lake has expanded and shrunk at various times. These processes may oscillate over short time periods on the scale of a human lifetime. The shoreline advance which was observed in the middle of the 20th century shows up well in the outlines of the last terrace; and areas which were recently been covered by water are visible on satellite images as flood plains with lots of small bushes and lakes.

There is, therefore, reason to believe that during different epochs the lake shoreline may have moved significantly depending on tectonic processes and climatic conditions. The basic source of terrigenous material on the northwest shore of the lake is the Bajirgarnak stream, and on the southeast the Ayuil and Muil-Tuk streams and the small river KungurTuk. According to our rough estimate, the terrigenous material which has been transported into the lake by the Ayuil stream alone amounts to approx. $3.5 \mathrm{~km}^{3}$. The length of the lake from the southwest on the northeast is $10 \mathrm{~km}$, its width in the middle about $5 \mathrm{~km}$, and the total lake area (including islands) is about $40 \mathrm{~km}^{2}$. The depth of the lake is insignificant, and on average not more than $0.5 \mathrm{~m}$.

\section{Continuous Aquatic Soundings (CAS)}

Data acquisition on the water area was done using a special marine streamer. A GPS receiver was installed on the leading boat to register the track of the marine streamer's beginning, whereas the position of the streamer's body, its center and the registration point were calculated using the boat's speed and course. The scheme representing the floating array used for continuous aquatic soundings is shown in Fig. 2. Its main feature is the mutual substitution of the current and potential electrodes. Together with the use of a multichannel receiver, it provides an enormous advantage: in a short moment of time equal to several periods of genera-

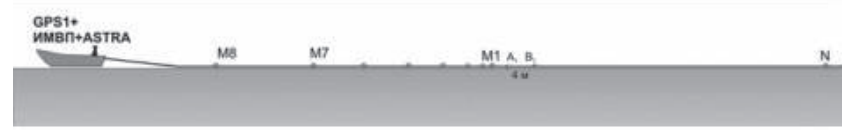

Figure 2: Inversed asymmetric Schlumberger array for continuous aquatic soundings.

ting a signal in the $\mathrm{AB}$ line, we can get a electrical sounding (ES) curve.

The 8-channel receiver used has a 24-digit ADC. This allows real-time data acquisition with a sampling rate of $2,5 \mathrm{kHz}$. The station's work frequency is usually set to $4.88 \mathrm{~Hz}$. During the acquisition, all signals are continuously recorded on the computer's hard disk. This makes it possible to do all the subsequent data processing in the laboratory. After a large number of averaging procedures over the data gridding results, an optimum $10 \mathrm{~m}$ step between sounding points was chosen, allowing to obtain $100 \mathrm{ES}$ curves per $\mathrm{km}$. Further development of the data processing software made it possible to obtain sounding points with $1 \mathrm{~m}$ steps for certain profiles. This high observation density allows the application of a two-dimensional inversion for the interpretation. $\mathrm{A}$ maximum $\mathrm{AO}$ (i.e. the distance between the furthest potential electrode and the center of the current electrodes) of $38 \mathrm{~m}$ allowed a research depth of $20 \mathrm{~m}$. The plan of the completed profiles is represented in Fig. 3. In all, a $35 \mathrm{~km}$ survey was carried out covering the central and southern

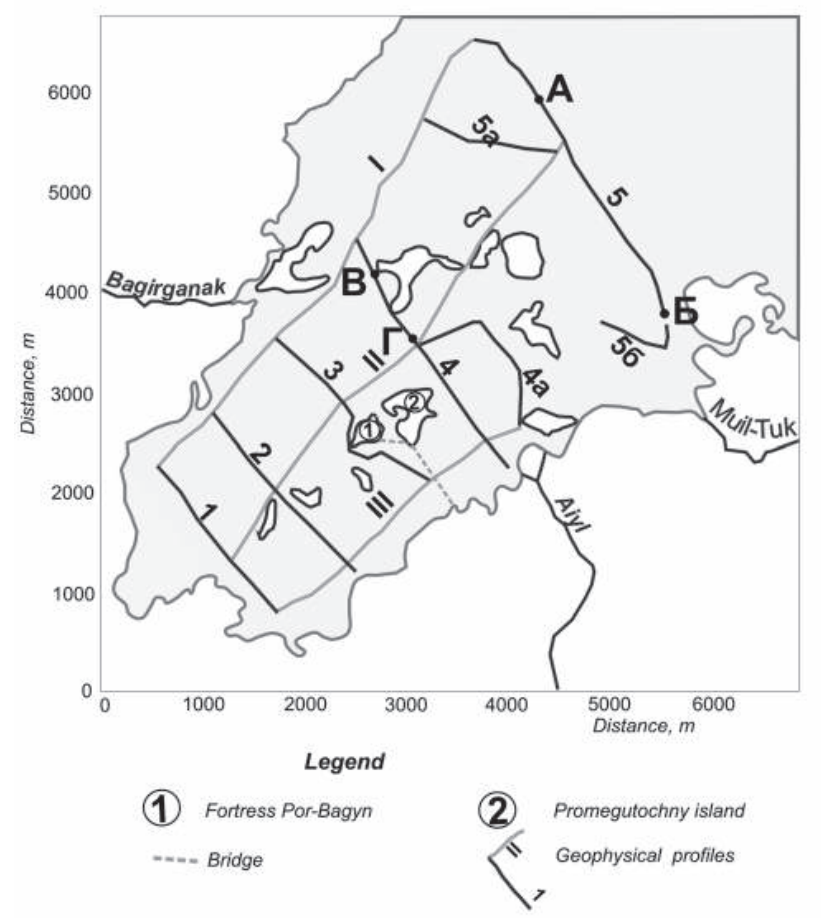

Figure 3: Survey plan of CAS on Lake Tere-Khol'. 
areas of the lake. Here the system of profile (net) was evenly spread to research the whole water area of the lake.

\section{ResUlts}

The further interpretation was carried out with respect to the division into eight cardinal electrophysical lithotypes. For this, the following parameters were applied: 1) the lake depth varies from 0.3 to $1.5 \mathrm{~m}$; 2) the apparent resistivity of the water varies from 45 to $50 \mathrm{ohm} . \mathrm{m}$; 3) the sandy loams must have a resistivity comparable to the resistivity of the water, i.e. around $45 \mathrm{ohm} \times \mathrm{m}$; 4) clay bonded sand must have one from 50 to $80 \mathrm{ohm} . \mathrm{m}, 5)$ medium-clayed sands from 80 to $100 \mathrm{ohm} . \mathrm{m}, 6)$ sorted low-clayed sands from 100 to $150 \mathrm{ohm} . \mathrm{m}, 7)$ well-sorted sands from 150 to 200 ohm.m, 8) rough sands more than $200 \mathrm{ohm} . \mathrm{m}$. Fig. 4 shows the interpreted CAS results for profile 5 between points A and B (see Fig. 3).

The acquired results show that at the time of the fortress construction, the open water area of the lake covered only the western part of today's extent of Lake Tere-Khol', and the fortress itself stood at the tip of a large peninsula that included the present-day Promezhutochnij island and a group of islands about $2 \mathrm{~km}$ to the northeast of Por-Bajin island. The southern shoreline of the lake was highly indented and appeared to have been a complex array of straits, islands and bays.

At that time there was a water area in the northeastern part of the lake (eastern conduction zone) that was joined to the south-western water area by a narrow strait. We estimate the width of the strait as having been $200 \mathrm{~m}$ at its eastern end and $500 \mathrm{~m}$ at its western end (to the north of the Promezhutichnij island).

\section{Conclusions}

Our studies of Lake Tere-Khol have produced the following results:

Continuous electrical soundings made a palaeogeographical reconstruction possible. It is reasonably certain that at the time when the fortress of Por-Bajin was built, open water existed only in the western part of the present-day extent of Lake Tere-Khol', to the west of the island of Por-Bajin. The fortress was therefore built on the tip of a large peninsula. At that time, there was also a lake area in the northeast part of Tere-Khol', and this was linked to the southwestern water area by a narrow strait.

A linear object was found between the fortress and Promezhutochnij island which was probably an isthmus linking the islands.

\section{References}

Khmelevskoy, P. I., Shevnin, V. K., 1988. Electrical soundings of geological environment. Moscow: Moscow State University (Rus).

WaInstein, S. I, 1964. Ancient Por-Bajin. Sovetskaya etnografiya, 103-114. (Rus).

Kuements, D. A., 1895. Archaeological diary of the northern Mongolian expedition of 1891. St Petersburg (Rus).

Maslov, P., 1933. The end of Uryankhai. Moscow: Molodaya gvardiya (Rus)

Bobachev, A.A., Zajtsev, D.A., Modin, I.N., Yakovlev, A.G., 2006. Electrometric research of tailing dams of ore-dressing factory. Razvedka I Ohrana Nedr, 12, December 2006, 25-29. (Rus).

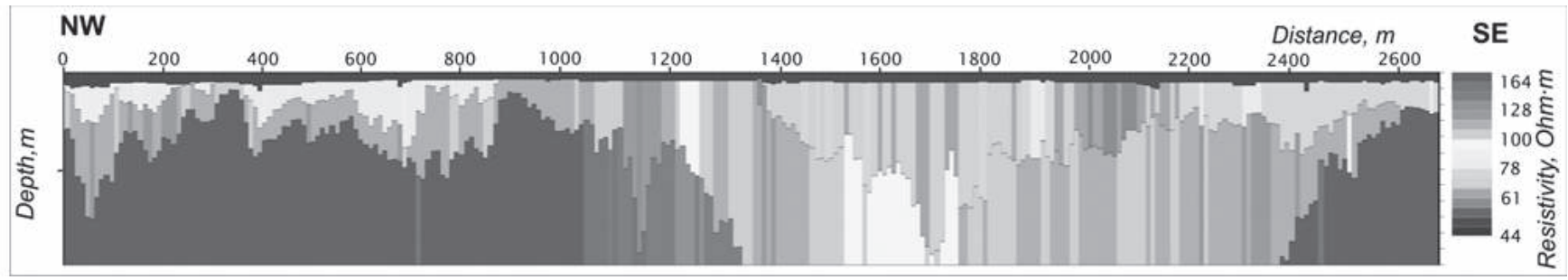

Figure 4 (see color plate): 1D-interpretation results for profile 5. Electrophysical lithotypes: 4- clay-bonded sand (50-80 ohm $\times \mathrm{m}), 5-6-$ medium- and low-clayed sands (80-150 ohm $\times \mathrm{m})$, 7-well-sorted sands $(150-200 \mathrm{ohm} \times \mathrm{m})$. 